\title{
PENGEMBANGAN BAHAN AJAR BERUPA MODUL BASICS ENGLISH GRAMMAR UNTUK MAHASISWA TADRIS BAHASA INGGRIS FITK IAIN SULTAN AMAI GORONTALO
}

\author{
Jhems Richard Hasan $^{(1)}$, Alvons Habibie ${ }^{(2)}$, Abdul Kadir Ismail ${ }^{(3)}$ \\ jrh@iaingorontalo.ac.id ${ }^{(1)}$, habibievons@iaingorontalo.ac.id ${ }^{(2)}$ abdulkadir89@ymail.com $^{(3)}$
}

Tadris Bahasa Inggris, FITK IAIN Sultan Amai Gorontalo

\begin{abstract}
Abstrak
Tujuan penelitian ini dirancang untuk: (1) Mengembangkan Bahan Ajar berbentuk modul Basics English Grammar untuk mahasiswa Tadris Bahasa Inggris FITK IAIN Sultan Amai Gorontalo; (2) Mengetahui kelayakan Bahan Ajar berbentuk modul Basics English Grammar. Penelitian ini merupakan penelitian pengembangan (Research and Development). Desain penelitian yang digunakan mengacu pada model pengembangan four-D (4D) models dengan empat tahapan pokok yaitu, (1) Define; (2) Design; (3) Develop; (4) Disseminate. Teknik pengumpulan data dalam penelitian ini yaitu dengan menggunakan angket dan $F G D$. Hasil riset ini berupa : (1) Pengembangan Bahan Ajar Berbentuk Modul Basic English Grammar sesuai dengan model pengembangan four-D models. Define, diperoleh hasil bahwa mahasiswa membutuhkan bahan ajar yang dapat meningkatkan kompetensi mahasiswa, serta membantu belajar mandiri. Design, diperoleh hasil bahan ajar yang sesuai kebutuhan mahasiswa berupa modul Basic English Grammar. Develop, dilakukan validasi oleh ahli, revisi sesuai saran ahli, serta uji coba pengembangan di semester 3 Tadris Bahasa Inggris. Disseminate, dilakukan penyebaran modul kepada mahasiswa Tadris Bahasa Inggris (2) Kelayakan Bahan Ajar Berbentuk Modul berdasarkan penilaian: ahli materi diperoleh rerata skor 3,93 (layak), ahli media diperoleh rerata skor 4,02 (layak), dan praktisi pembelajaran/dosen pengampu mata kuliah Grammar diperoleh rerata skor 4,03 (layak); (3) Penilaian mahasiswa terhadap Bahan Ajar Berbentuk Modul Basic English Grammar diperoleh rerata skor 4,33 (sangat layak).
\end{abstract}

Kata Kunci: Bahan Ajar, Modul Basic English Grammar, Model Pengembangan Four-D

\begin{abstract}
The purposes of this study were designed to: (1) develop teaching and learning materials in the form of a Basics English Grammar module for students of the English Department, Faculty of Teacher Training IAIN Sultan Amai Gorontalo; (2) find out the feasibility of teaching and learning materials in the form of a Basics English Grammar module. This study is research and development in nature. The research design used refers to the four-D (4D) models of development with four main stages namely, (1) Define; (2) Design; (3) Develop; (4) Disseminate. Data collection techniques in this study were using questionnaires and FGD. The results of this study are: (1) Development of Basic English Grammar Module Teaching Materials in accordance with the four-D model development model. In the fisrt step of the model Define, the results show that students need teaching materials that can improve student competence, as well as help independent learning. Design, the results of teaching materials that are suitable for students' needs are in the form of Basic English Grammar modules. Develop, carried out validation by experts, revised according to expert advice, and trial development in the 3rd semester of English Education Department. Disseminate, the module is disseminated to English Education students (2) Feasibility of Module-Based Teaching Materials based on assessment: material experts obtained a mean score of 3.93 (feasible), media experts obtained a mean score of 4.02 (appropriate), and learning practitioners / lecturers the average Grammar subject is 4.03 (feasible); (3) Student's assessment of Teaching Materials in the Form of Basic English Grammar Modules obtained a mean score of 4.33 (very feasible).
\end{abstract}

Keywords:Teaching and Learning Material, Basic English Grammar Module, Four-D Model. 
Al-Lisan. Journal Bahasa \& Pengajarannya

ISSN 2442-8965 \& E ISSN 2442-8973

Volume 4 Nomor 1- Februari 2019

http://journal.iaingorontalo.ac.id/index.php/al

\section{A. PENDAHULUAN}

Menurut UU No. 20 Tahun 2003 tentang SISDIKNAS pasal 1 ayat 20, pembelajaran merupakan proses interaksi peserta didik dengan pendidik dan sumber belajar pada suatu lingkungan belajar. Definisi in menggambarkan pentingnya proses penciptaan interaksi yang dilakukan oleh guru terhadap muridnya begitupula sebaliknya. Proses interaksi ini tentu memerlukan sebuah alat bantu untuk menjembatani proses pembelajaran di dalam kelas untuk mencapai tujuan dari proses pembelajaran itu sendiri. Alat bantu yang dimaksud adalah bahan ajar. Sebagaimana yang dikemukakan oleh suhertian (2004) bahwa bahan ajar mengambil peranan penting dalam mewujudkan tujuan pembelajaran yang berkualitas, dari hasil penelitiannya menyimpulkan bahwa bahan ajar mempunyai pengaruh yang siginifikan terhadap hasil belajar. Ini berarti pembelajaran yang menggunakan bahan ajar cenderung memperoleh hasil yang lebih baik dibandingkan dengan yang tidak menggunakan bahan ajar.

Dari hasil observasi awal, penulis menemukan beberapa fakta mengenai proses pembelajaran Basic English Grammar di lingkungan IAIN Sultan Amai, khususnya di jurusan Tadris Bahasa Inggris; (1) Proses pembelajaran selama ini belum menggunakan bahan ajar yang sama, masing masing dosen mempunyai bahan ajar berbeda-beda. Dari hasil wawancara dosen bahasa inggris, ditemukan bahwa penyusunan bahan ajar hanya berdasarkan pemikiran dosen masing-masing dan sumber materi hanya mengambil dari internet dan buku-buku bahasa Inggris yang sudah jadi. (2) Materi yang diajarkan dan dituangkan dalam silabus atau RPP selama ini juga berbeda-beda, bahkan materi atau topik juga berbeda tiap tahunnya. (3) mahasiswa belum pernah pernah mempunyai buku pegangan yang bisa digunakan sebagai bahan belajarnya ketika ada di rumah, selama ini materi hanya dijelaskan mengggunakan metode tradisional yaitu menuliskan materinya di papan tulis selama proses pembelajaran di kelas berlangsung. (4) sistem evaluasi terkadang tidak berdasarkan pada acuan materi atau topik yang telah diajarkan. (5) mata kuliah grammar menjadi mata kuliah paling banyak yang tidak disukai oleh mahasiswa.

Masalah tersebut di atas tentu sedikit memberi gambaran bahwa pembelajaran Basic English Grammar di Tadris Bahasa Inggris perlu dan penting untuk dicarikan solusinya. Pembelajaran grammar merupakan aspek penting penopang empat skill utama dalam bahasa. Keterampilan bahasa berupa speaking, listening, reading dan writing tidak dapat dipisahkan dari proses pembelajaran grammar itu sendiri. Proses 
Al-Lisan. Journal Bahasa \& Pengajarannya

ISSN 2442-8965 \& E ISSN 2442-8973

Volume 4 Nomor 1- Februari 2019

http://journal.iaingorontalo.ac.id/index.php/al

pembelajaran grammar yang dimaksud adalah pembelajaran yang mampu meningkatkan motivasi dan minat mahasiswa untuk mendalami serta menekuni mata kuliah grammar, khususnya pada tataran basic, intermediate, dan advance.

Agar membuat pembelajaran Basic English Grammar lebih terarah dan menyenangkan, maka dipandang perlu untuk dibuatkan sebuah buku ajar yang komunikatif dan mampu membangkitkan gairah belajar mahasiswa. Oleh karena itu penulis bermaksud melakukan riset dan pengembangan materi ajar Basic English Grammar yang digunakan sebagai modul pegangan dosen dan mahasiwa pada semester tiga Tadris Bahasa Inggris IAIN Sultan Amai Gorontalo.

Sebelum mengembangkan Modul atau materi ajar, perlu adanya bangunan teoritis yang kuat untuk mendukung penelitian ini. Beberapa definisi ahli mengenai bahan ajar atau materi ajar didefinisikan sebagai berikut. Menurut Tomlinson (1998:2) materi ajar adalah segala sesatu yang digunakan oleh guru dan siswa dalam upaya memudahkan belajar bahasa sehingga dapat meningkatkan pengetahuan dan atau penglaman berbahasa.

Dick, Carey, dan Carey (2009: 230) menambahkan bahwa instructional material contain the conten either written, mediated, or facilitated by an instructor that a student as use to achieve the objective also include information thet the learners will use to guide the progress. Berdasarkan ungkapan Dick, Carey, dan Carey dapat diketahui bahwa bahan ajar berisi konten yang perlu dipelajari oleh siswa baik berbentuk cetak atau yang difasilitasi oleh pengajar untuk mencapai tujuan tertentu.

Iskandarwassid dan Dadang Sunendar (2011: 171) mengungkapkan bahwa bahan ajar merupakan seperangkat informasi yang harus diserap peserta didik melalui pembelajaran yang menyenangkan. Hal ini menunjukkan bahwa dalam penyusunan bahan ajar diharapkan siswa benar-benar merasakan manfaat bahan ajar atau materi itu setelah ia mempelajarinya. Yana Wardhana (2010: 29) menambahkan bahwa bahan ajar merupakan suatu media untuk mencapai keinginan atau tujuan yang akan dicapai oleh peserta didik. Sedangkan menurut Opara dan Oguzor (2011: 66) mengungkapkan bahwa instructional materials are the audio visual materials (software/hardware) which can be used as alternative channels of communication in the teaching-learning process. Bahan ajar merupakan sumber belajar berupa visual maupun audiovisual yang dapat digunakan sebagai saluran alternatif pada komunikasi di dalam proses pembelajaran. 
Al-Lisan. Journal Bahasa \& Pengajarannya

ISSN 2442-8965 \& E ISSN 2442-8973

Volume 4 Nomor 1- Februari 2019

http://journal.iaingorontalo.ac.id/index.php/al

Berdasarkan kajian di atas, istilah bahan ajar yang digunakan dalam penelitian ini adalah suatu bahan/ materi pelajaran yang disusun secara sistematis yang digunakan dosen dan mahasiswa dalam pemebelajaran Basic English Grammar untuk mencapai tujuan yang diharapkan.

Pengembangan suatu bahan ajar harus didasarkan pada analisis kebutuhan siswa/mahasiswa. Terdapat sejumlah alasan mengapa perlu dilakukan pengembangan bahan ajar, seperti yang disebutkan oleh Direktorat Pembinaan Sekolah Menengah Atas (2008: 8-9) sebagai berikut.

a. Ketersediaan bahan sesuai tuntutan kurikulum, artinya bahan belajar yang dikembangkan harus sesuai dengan kurikulum

b. Karakteristik sasaran, artinya bahan ajar yang dikembangkan dapat disesuaikan dengan karakteristik siswa/mahasiswa sebagai sasaran, karakteristik tersebut meliputi lingkungan sosial, budaya, geografis maupun tahapan perkembangan siswa/mahasiswa

c. Pengembangan bahan ajar harus dapat menjawab atau memecahkan masalah atau kesulitan dalam belajar.

Dengan demikian, pengembangan bahan ajar di sekolah atau perguruan tinggi perlu memperhatikan karakteristik siswa/mahasiswa dan kebutuhan siswa/mahasiswa sesuai kurikulum, yaitu menuntut adanya partisipasi dan aktifitas siswa lebih banyak dalam pembelajaran. Pengembangan lembar kegiatan siswa menjadi salah satu alternatif bahan ajar yang akan bermanfaat bagi siswa menguasai kompetensi tertentu, karena lembar kegiatan siswa dapat membantu siswa menambah informasi tentang materi yang dipelajari melalui kegiatan belajar secara sistematis

Secara umum bahan ajar dapat dibedakan ke dalam bahan ajar cetak dan noncetak. Bahan ajar cetak dapat berupa, handout, buku, modul, brosur, dan lembar kerja siswa. Sedangkan bahan ajar noncetak meliputi, bahan ajar audio seperti, kaset, radio, piringan hitam, dan compact disc audio. Bahan ajar audio visual seperti, CAI (Computer Assisted Instruction), dan bahan ajar berbasis web (web based learning materials) (Ika Lestari, 2013: 5).

Lebih lanjut Mulyasa (2006: 96) menambahkan bahwa bentuk bahan ajar atau materi pembelajaran antara lain adalah bahan cetak (hand out, buku, modul, LKS, brosur, dan leaflet), audio (radio, kaset, cd audio), visual (foto atau gambar), audio 
Al-Lisan. Journal Bahasa \& Pengajarannya

ISSN 2442-8965 \& E ISSN 2442-8973

Volume 4 Nomor 1- Februari 2019

http://journal.iaingorontalo.ac.id/index.php/al

visual (seperti; video/ film atau VCD) dan multi media (seperti; CD interaktif, computer based, dan internet).

Bahan ajar yang dimaksud dalam kajian ini lebih ke bahan ajar cetak berupa buku teks. Hal ini dikarenakan, buku teks sangat erat kaitannya dengan kurikulum, silabus, standard kompetensi, dan kompetensi dasar. Rudi Susilana (2008: 14) mengungkapkan bahwa buku teks adalah buku tentang suatu bidang studi atau ilmu tertentu yang disusun untuk memudahkan para guru dan siswa dalam upaya mencapai tujuan pembelajaran.

Buku teks mempunyai peran penting dalam pencapaian tujuan pendidikan nasional. Hutchinson \& Torres (1994) mengungkapkan bahwa The textbook is an almost universal element of [English language] teaching. Millions of copies are sold every year, and numerous aid projects have been set up to produce them in [various] countries...No teaching-learning situation, it seems, is complete until it has its relevant textbook. Buku teks merupakan salah satu unsure yang dibutuhkan dalam pengajaran. Buku teks dapat juga menjadi wadah untuk menuliskan ide-ide terkait kebudayaan nasional suatu bangsa. Sebagaimana yang diungkapkan Pingel (2009: 7) bahwa Textbooks are one of the most important educational inputs: texts reflect basic ideas about a national culture, and are often a flashpoint of cultural struggle and controversy.

Proses pembelajaran grammar mengambil peran penting dalam mendukung keempat keterampilan berbahasa Inggris pada umumnya. Asumsi bahwa pembelajaran bahasa berfokus pada pemaknaan atau komunikasi dipandang belum cukup untuk mencapai kompetensi kebahasaan secara menyeluruh. Di bawah ini penulis mencoba menjabarkan mengenai grammar berrdasarkan pada teori-teori pakar bahasa. Menurut Harmer (2001:142), tata bahasa merupakan penjelasan cara bagaimana kata - kata diubah dan digabungkan pada kalimat di dalam suatu bahasa (grammar is the description of the ways in which words can change their forms and can be combined into sentences in that language). Tata bahasa adalah salah satu aspek yang paling penting dalam penerjemahan

Senada dengan itu, Swan (2005:19), mendefinisikan grammar "the rules that show how words are combined, arranged or changed to show certain kinds of 
Al-Lisan. Journal Bahasa \& Pengajarannya

ISSN 2442-8965 \& E ISSN 2442-8973

Volume 4 Nomor 1- Februari 2019

http://journal.iaingorontalo.ac.id/index.php/al

meaning."(Grammar adalah aturan yang menerangkan bagaimana kata digabungkan, disusun atau diubah untuk menunjukkan beberapa jenis makna).

Selain definisi yang umum seperti di atas, ada beberapa pakar bahasa yang mendefinisikan grammar dengan gaya yang berbeda seperti Greenbaum dan Leech. Leech dkk (1982:3) mendefinisikan grammar sebagai:"reference to the mechanism according to which language works when it is used to communicate with other people. Grammar is a mechanism for putting words together, but we have said little about sound of meaning."(Makna Grammar adalah referensi mekanisme menurut fungsi bahasa ketika digunakan dalam komunikasi dengan orang lain. Grammar adalah aturan untuk penggabungan kata, tetapi kami telah menjelaskan sedikit tentang bunyi suatu makna). Sedangkan tata bahasa (grammar) menurut Gerot dan Wignell (1995: 2), "Grammar is a theory of language, of how language is put together and how it works".

Dari beberapa kutipan penjelasan menurut pakar bahasa di atas dapat bahasakan kembali bahwa grammar (tata bahasa) merupakan aturan dalam suatu bahasa yang menggabungkan kata sehingga menjadi susunan yang dapat dipahami penerapan dan cara kerjanya.

Menurut Gerot dan Wignell (1995) dalam bukunya "Making Sense of Functional grammar terdapat tiga grammar yang dipelajari di dunia pendidikan abad ini, yaitu:

1. Tata bahasa tradisional (Traditional grammar) bertujuan menggambarkan standarisasi grammar bahasa Inggris yang dibandingkan dengan Latin. Tata bahasa tradisional lebih fokus pada peraturan-peraturan dalam memproduksi kalimat yang benar.

2. Tata bahasa formal (Formal grammar) bertujuan menggambarkan strukturstruktur kalimat. Pertanyaan yang tepat yang dapat terjawab oleh Tata bahasa formal yaitu "How is this sentence structured?

3. Tata bahasa fungsional (Functional grammar) menggambarkan bahasa sebagai makna yang terfokus pada teks dan konteks. Tata bahasa fungsional diawali dengan pertanyaan "How are the meanings of this text realized?"

Dari ketiga model tersebut yang dikemukakan Gerot dan Wignell di atas, penelitian ini mengambil ketiga model tersebut untuk diramu dan dikembangkan menjadi sebuah modul pembelajaran yang komunikatif dengan menampilkan pembelajaran tata bahasa berbasis gambar. 
Al-Lisan. Journal Bahasa \& Pengajarannya

ISSN 2442-8965 \& E ISSN 2442-8973

Volume 4 Nomor 1- Februari 2019

http://journal.iaingorontalo.ac.id/index.php/al

\section{Penelitian Terdahulu yang Relevan}

Penelitian terdahulu yang relevan dengan penelitian ini adalah sebagai berikut: Pengembangan bahan ajar grammar one berbasis mobile learning di lembaga kursus Global English Pare - Kediri. Dari kajian penelitian yang dilakukan oleh Syahrul Mubaroq pada tahun 2015, penelitian ini bertujuan untuk mengembangkan bahan ajar grammar one berbasis mobile learning dengan menggunakan model pengembangan Lee \& Owens. Sedangkan penelitian yang dilakukan peneliti adalah pengembangan modul pembelajaran grammar dengan penjelasan materi berbasis gambar dengan menggunakan model pengembangan Borg \& Gall. Hasil penelitian ini menunjukkan bahwa produk pengembangan bahan ajar Grammar One ini dapat digunakan dalam pembelajaran sebagai pelengkap pembelajaran di kelas maupun dapat dijadikan sumber belajar secara mandiri.

Penelitian selanjutnya adalah penelitian yang dilakukan oleh Hendra Eka Putra \& Ridianto tahun 2016 dengan judul pengembangan model materi ajar mata kuliah bahasa inggris 2 berbasis kebutuhan mahasiswa program studi Akuntansi Syariah STAIN Batusangkar. Tujuan Penelitian ini adalah mendesain model pembelajaran bahasa inggris yang difokuskan pada keterampilan membaca. Perbedaan antara penelitian ini dan penelitian yang peneliti lakukan adalah pada objek dan subjek penelitian yang dikembangkan.

\section{B. METODE PENELITIAN}

Penelitian ini menggunakan pendekatan Research \& Development (Penelitian dan Pengembangan). Penelitian ini merupakan suatu proses atau langkah-langkah untuk mengembangkan suatu produk baru atau menyempurnakan produk yang sudah ada dan dapat dipertanggungjawabkan. Penelitian ini mengacu pada model penelitian dan pengembangan 4D (four-D) yang dikemukakan oleh Thiagarajan, Semmel dan Semmel (dalam Trianto, 2010: 189). Model pengembangan ini terdiri dari 4 tahap yaitu pendefinisian (Define), Perancangan (Design), Pengembangan (Develop), dan Penyebaran (Disseminate).

Lokasi penelitian adalah di jurusan Tadris Bahasa Inggris, Fakultas Ilmu Tarbiyah dan Keguruan, IAIN Sultan Amai Gorontalo 
Al-Lisan. Journal Bahasa \& Pengajarannya

ISSN 2442-8965 \& E ISSN 2442-8973

Volume 4 Nomor 1- Februari 2019

http://journal.iaingorontalo.ac.id/index.php/al

Subjek penelitian ini adalah mahasiswa Tadris Bahasa Inggris yang akan dbagi ke dalam dua kelompok uji coba, yaitu uji coba kelompok kecil dan uji coba kelompok besar.

Prosedur Penelitian ini mengadapsi prosedur penelitian pengembangan yang dikembangkan oleh Thiagarajan, Semmel dan Semmel dengan skema berikut:

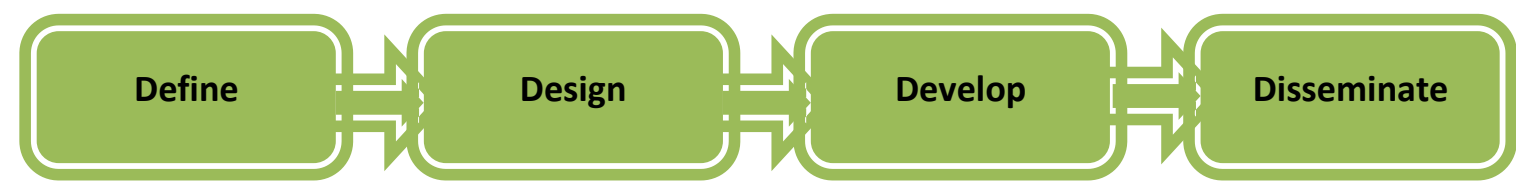

Untuk mengetahui kualitas produk yang dikembangkan, maka diperlukan data kualitatif dan data kuantitatif. Data kualitatif berupa kritik, saran, dan masukan dari para ahli, dosen, dan mahasiswa untuk perbaikan modul Basic English Grammar. Data kuantitatif berupa skor tanggapan tentang kualitas produk baik dari pakar, dosen, dan mahasiswa. Pengumpulan data dilakukan dengan beberapa membuat angket. Penggunaan angket ini dimaksudkan untuk mendapatkan data tentang kelayakan modul pembelajaran Basic English Grammar. Angket yang digunakan dalam penelitian ini ada dua macam, yakni: a) angket untuk penilaian produk oleh ahli materi dan media; b) angket penerimaan dan respon praktisi pembelajaran dan mahasiswa.

Teknik analisis data menggunakan teknik analisis deskrptif kuantitatif. Data yang dianalisis meliputi analisis kelayakan, respon siswa, Analisis kelayakan modul oleh ahli, dosen, dan mahasiswa.

Analisis Kelayakan Produk. Data untuk analisis kelayakan produk didapat dari angket validasi oleh ahli materi, dosen ahli media dan praktisi pembelajaran akuntansi. Angket tersebut terdiri dari lima pilihan jawaban dengan skala interval 1 sampai 5 . Teknik analisis ini dilakukan dengan langkah-langkah berikut: a) Tabulasi data; b) Menghitung skor rata-rata; c) mengubah skor rata-rata menjadi nilai dengan kategori.

\section{HASIL DAN PEMBAHASAN}

\section{Hasil}

Pengembangan bahan ajar berupa modul dalam penelitian ini merujuk pada model atau prosedur pengembangan yang dikembangkan oleh Thiagarajan dan Semmel yang dikenal dengan istilah Four-D (4D) models. Tahap-tahap ini meliputi: (a) Define atau pendefinsiai, (b) Design atau perancangan, (c) Develop atau pengembangan dan (d) 
Al-Lisan. Journal Bahasa \& Pengajarannya

ISSN 2442-8965 \& E ISSN 2442-8973

Volume 4 Nomor 1- Februari 2019

http://journal.iaingorontalo.ac.id/index.php/al

Disseminate atau tahap penyebaran produk. Adapun temuan dari setiap tahapan teserbut dijabarkan sebagai berikut:

1. Define (Pendefinisian)

Langkah awal pada tahap ini adalah mengumpulkan informasi dan menganalisis kebutuhan mahasiswa dan dosen bahasa Inggris di lingkungan Fakultas Ilmu Tarbiyah dan Keguruan IAIN Sultan Amai Gorontalo. Pengumpulan informasi kebutuhan terhadap pengembangan produk berupa modul atau bahan ajar pada mata kuliah Basic English Grammar ini dilakukan dengan menyebarkan angket kebutuhan dan melalui Focus Group Discussion (FGD). Dari hasil angket dan kegiatan focus group discussion ini kemudian diuraikan dan dianalisis segala bentuk kebutuhan dosen dan mahasiswa sebagai langkah awal dalam mengembangkan produk berupa modul atau bahan ajar pada mata kuliah Basic English Grammar di Jurusan Tadris Bahasa Inggris FITK IAIN Sultan Amai Gorontalo.

a. Hasil Angket

Angket yang disebarkan ke beberapa mahasiswa bertujuan untuk mengetahui kebutuhan dasar mahasiswa dalam pembelajaran pada mata kuliah English Basic Grammar. Dari hasil angket ini didapati informasi mengenai proses pembelajaran dan kemampuan awal mahasiswa serta kebutuhan dasar mahasiswa pada mata kuliah English basic grammar sebagai berikut:

1). Proses pembelajaran English Basic Grammar di semester III Tadris Bahasa Inggris selama ini menggunakan metode konvensional atau tradisional, dimana dosen mentik beratkan pengajaran pada aspek materi yang berisi tentang hapalan-hapalan rumus yang banyak dan cukup membingungkan mahasiswa.

2). Buku ajar sebagai media dalam proses pembelajaran tidak dibagikan, namun hanya disampaikan melalui pembahasan langsung dalam kelas, bahkan referensi buku yang dirujuk hanya bersumber pada salah satu buku grammar saja.

3). Hasil pembelajaran hanya berfokus pada sejauhmana mahasiwa dapat menghafalkan rumus-rumus dalam membentuk kalimat bahasa Inggris dengan baik dan tepat sesuai kaidah tata bahasa yang berlaku.

4). Sistem evaluasi pembelajaran tidak mampu mengukur kemampuan mahasiswa yang sebenarnya. Atau dengan kata lain, alat evaluasi yang digunakan tidak sesuai dengan tujuan pembelajaran Basic English Grammar itu sendiri. 
Al-Lisan. Journal Bahasa \& Pengajarannya

ISSN 2442-8965 \& E ISSN 2442-8973

Volume 4 Nomor 1- Februari 2019

http://journal.iaingorontalo.ac.id/index.php/al

5). Secara umum kemampuan tata bahasa mahasiswa pada level dasar atau basic masih dapat dikategorikan sedang. Hal ini dibuktikan dengan hasil belajar mahasiswa pada mata kuliah tersebut dimana sebagian besar mahasiswa mendapatkan nilai di bawah $3.50(\mathrm{~A}-)$.

6). Pada aspek mengenai harapan mahasiswa dalam pembelajaran Basic English Grammar, sebagian besar mahasiswa mengharapkan adanya sebuah produk atau media pembelajaran berupa modul atau bahan ajar yang baku dan dibagikan kepada mahasiswa.

b. Hasil Focus Group Discussion (FGD)

Kegiatan ini dilakukan untuk melihat dan mendengarkan langsung mengenai keluhan dan merumuskan solusi dalam pembelajaran Basic English Grammar. Kegiatan ini melibatkan dosen pengajar dan mahasiwa Tadris Bahasa Inggris. Dosen pengajar yang diundang adalah dosen yang memang bergelut dalam bidang English grammar sebanyak 2 orang wakil dosen. Mahasiwa bahasa Inggris yang mewakili tiga angkatan mulai dari angkatan 2015 sampai angkatan 2017, dan kami sebagai peneliti berjumlah 3 orang. Dalam diskusi ini, kami sebagai peneliti mengarahkan topik diskusi pada (1) apa saja keluhan yang dirasakan dan dialami langsung oleh dosen dan mahasiswa dalam proses pembelajaran yang berlangsung di dalam kelas. (2) apa yang diharapakan? atau kebutuhan dosen dan mahasiswa apa yang paling dibutuhkan dalam pembelajaran Basic English Grammar?.

Dari hasil pertemuan merumuskan beberapa hasil kesepakatan bersama antara peneliti, dosen dan mahasiswa sebagai berikut:

a. Produk pembelajaran atau media pembelajaran berupa modul atau bahan ajar yang baku sangat diharapkan ada atau tersedia dalam bentuk cetak.

b. Materi pembelajaran agar disesuaikan dengan komptensi dasar yang ingin dicapai, atau dengan kata lain, materi harus mencerminkan segala aspek yang dibutuhkan mahasiswa pada level dasar pada mata kuliah Basic English Grammar itu sendiri.

c. Materi pembelajaran agar mudah dipahami dan dilengkapi dengan ilustrasi atau gambar-gambar yang menarik dan bisa membangkitkan gairah belajar mahasiswa. 
Al-Lisan. Journal Bahasa \& Pengajarannya

ISSN 2442-8965 \& E ISSN 2442-8973

Volume 4 Nomor 1- Februari 2019

http://journal.iaingorontalo.ac.id/index.php/al

d. Materi pembelajaran grammar agar lebih aplikatif atau dapat diterpakan langusung dan tidak menitik beratkan pada hafalan-hafalan rumus dan kosa kata

e. Bahasa yang digunakan dalam modul menggunakan bahasa Inggris sederhana atau bahasa Indonesia sehingga memudahkan mahasiswa dalam memahami setiap penjelasan dan instruksi dalam modul secara mandiri

f. Mengurangi atau menyederhanakan setiap penjelasan atau instruksi dalam modul, sehingga tidak membuat mahasiswa bosan untuk membacanya.

g. Penjelasan setiap materi terdapat ilustrasi sederhana berupa gambar atau tabel sederhana yang mampu memberikan gambaran dan pemahaman langsung tanpa harus membaca keseluruhan uraian.

h. Alat evaluasi yang digunakan beragam dan posisinya pada setiap akhir topik pembelajaran

Dari hasil analisis kebutuhan dosen dan mahasiswa melalui dua cara tersebut di atas, tim peneliti menyimpulkan bahwa penting untuk mengembangkan bahan ajar berupa modul Basic English Grammar pada mahasiswa Tadris Bahasa Inggris khususnya pada semester III. Produk yang dikembangkan merupakan pengembangan lanjutan dari berbagai bahan ajar yang sudah tersedia baik secara online maupun offline, namun dengan memperhatikan dan mempertimbangkan segala aspek yang dibutuhkan mahasiswa sehingga proses pembelajaran menggunakan modul ini sesuai dengan karakter dan kebutuhan bersama dosen dan mahasiswa. Ciri khas utama modul yang dikembangkan adalah terletak pada ilustrasi grambar dan tabel yang ditampilkan pada setiap topik sehingga memudahkan mahasiswa dalam memahami setiap materi dengan baik. Serta alat evaluasi yang variatif dan menantang namun menarik.

Langkah kedua adalah telaah pustaka atau dokumen. Pada tahap ini tim peneliti melakukan kajian terhadap modul atau buku ajar yang sudah beredar baik dalam bentuk e-modul atau printed modul. Dari hasil kajian dari beberapa modul tersebut, tim peneliti menemukan bahwa terdapat berbagai bentuk sajian atau format modul itu sendiri. Keberagaman dalam tampilan isi modul ini juga menambah khasanah tim peneliti dalam mengembangakan modul English Basic Grammar. Namun, perbedaan itu juga yang menginspirasi tim peneliti untuk mengembangkan produk berupa bahan ajar atau modul dengan ciri khas berupa tampilan gambar dan tabel-tabel sehingga memudahkan 
Al-Lisan. Journal Bahasa \& Pengajarannya

ISSN 2442-8965 \& E ISSN 2442-8973

Volume 4 Nomor 1- Februari 2019

http://journal.iaingorontalo.ac.id/index.php/al

pembaca atau pembelajar itu sendiri. Tampilan atau format yang disajikan sederhana namun padat dan jelas. Pada langkah ini pula tim peneliti banyak mendapatkan inspirasi dalam membuat evaluasi atau latihan-latihan soal pada setiap materinya. Model evaluasi atau latihan dibuat beragam dan mendorong mahasiswa untuk belajar menyelesaikan setiap model latihan tersebut.

Langkah ketiga, Setelah melakukan telaah pustaka atau dokumen di atas, maka langkah selanjutnya adalah menentukan cakupan materi. Cakupan materi tersebut disesuaikan dengan kurikulum dan tingkat kemampuan mahasiswa. Berdasarkan analisis kebutuhan mahasiswa dan telaah pustaka atau dokumen di atas, materi yang dituangkan dalam modul pada penelitian ini adalah materi dasar grammar yang mencakup Parts of Speech. Materi ini sangat penting untuk dikuasai terlebih dahalu bagi seorang pembelajar bahasa, khususnya pada komptensi kebahasaan berupa tata bahasa.

Langkah keempat, Tahap ini dilakukan untuk merumuskan hasil telaah pustaka atau dokumen dan analisis materi yang sebelumnya telah dilakukan. Indikator yang muncul dari analisis kurikulum dan analisis materi akan menjadi tujuan pembelajaran sekaligus sebagai dasar penyusunan butir soal. Berdasarkan telaah pustaka atau dokumen dan analisis materi, diperoleh spesifikasi tujuan dari masing-masing kompetensi dasar.

2. Design (Perancangan)

Tahap perancangan dilakukan untuk merancang bahan ajar yang dikembangkan. Terdapat empat langkah yang dilakukan pada tahap perancangan ini, yaitu:

a. Penyusunan tes

Soal tes termuat dalam satu paket soal praktik yang terdiri dari lembar soal dan lembar kerja. Lembar soal yang diberikan terdiri dari informasi umum, instruksi mengerjakan soal dan soal pemahaman tentang part of speech dalam bentuk pilihan ganda.

b. Pemilihan media

Pemilihan media dilakukan untuk menentukan media yang tepat dalam penyajian materi pembelajaran serta sesuai dengan tujuan pembelajaran. Pemilihan media ini didasarkan pada analisis yang dilakukan sebelumnya pada tahap define. Berdasarkan analisis yang dilakukan diperoleh informasi bahwa pada mata Kuliah English Basic Grammar diperlukan pengembangan bahan ajar yang dapat digunakan mahasiswa untuk 
Al-Lisan. Journal Bahasa \& Pengajarannya

ISSN 2442-8965 \& E ISSN 2442-8973

Volume 4 Nomor 1- Februari 2019

http://journal.iaingorontalo.ac.id/index.php/al

belajar secara mandiri dan dapat meningkatkan kompetensi mahasiswa. Dengan demikian, media yang dikembangkan dalam penelitian ini adalah Bahan Ajar Grammar Berbentuk Modul. Alasan pemilihan modul karena modul merupakan bahan ajar yang disusun secara sistematis sesuai tingkat pengetahuan mahasiswa agar dapat digunakan belajar secara mandiri oleh mahasiswa. Bentuk dari Bahan Ajar Grammar berbentuk Modul yang dikembangkan adalah media cetak.

c. Pemilihan format

Pemilihan format dilakukan dengan memilih format dari media yang dikembangkan dengan mengkaji format-format yang sudah ada dan sudah dikembangkan. Format yang dimaksudkan dalam penelitian ini adalah komponenkomponen yang harus ada dalam penyusunan modul sesuai dengan kajian pustaka yang telah dilakukan. Berdasarkan analisis kajian teori yang telah dilakukan, maka format dari Bahan Ajar English Basic Grammar Berbentuk Modul memuat hal-hal berikut:

1) Bagian Pembuka

a) Halaman sampul

b) Kata pengantar

c) Daftar isi, daftar Tabel, daftar gambar

2) Kegiatan belajar

a) Pengantar

b) Uraian materi beserta contoh dan latihan

c) Rangkuman

d) Tes formatif

e) Tugas

f) Lembar kerja

g) Kunci jawaban

5) Evaluasi

6) Daftar pustaka

d. Penulisan Naskah

Penulisan naskah dilakukan dengan tahap berikut:

1) Menetapkan Judul Modul

Judul Modul yang dikembangkan adalah "Basic English Grammar; Practical and Understandable" 
Al-Lisan. Journal Bahasa \& Pengajarannya

ISSN 2442-8965 \& E ISSN 2442-8973

Volume 4 Nomor 1- Februari 2019

http://journal.iaingorontalo.ac.id/index.php/al

2) Menetapkan Tujuan Akhir dan Antara

3) Menyusun Garis-Garis Besar Konten Modul

4) Mengembangkan Materi

\section{Develop (Pengembangan)}

Tahap pengembangan ini bertujuan untuk menghasilkan produk akhir dengan melewati beberapa tahap sebagai berikut:

a. Validasi Ahli

Hasil rancangan modul oleh tim peneliti pada tahap sebelumnya harus melalui validasi ahli sebelum diujicobakan pada kelompok kecil. Tujuan validasi ini adalah untuk mengetahui kelayakan modul yang telah dikembangkan. Validator dalam peelitian ini terdiri dari validator materi, validator media dan dosen pengampu MK Basic English Grammar. Validator memberikan penilaian dan saran berdasarkan lembar penilian yang telah disediakan oleh tim peneliti.

1) Hasil Uji Kelayakan Ahli Materi

Materi modul dalam penelitian ini diuji dengan menggunakan format penilaian berbentuk angket dengan skala 5. Angket berisi 31 butir pernyataan yang dikelompokkan dalam 3 aspek yaitu kelayakan isi, penggunaan bahasa dan penyajian. Hasil rata-rata penilaian disajikan dalam tabel berikut:

Tabel 1. Uji Kelayakan Ahli Materi

$\begin{array}{llll}\text { No } & \text { Aspek Penilaian } & \text { Rata-Rata Skor } & \begin{array}{r}\text { Kategori } \\ \text { Layak }\end{array} \\ 1 & \text { Isi } & 4,00 & \text { Layak } \\ 2 & \text { Penggunaan Bahasa } & 3,91 & \text { Layak } \\ 3 & \text { Penyajian } & 3,89 & \text { Layak }\end{array}$

Dari hasil validasi oleh ahli materi di atas dapat disimpulkan bahwa pengembangan produk tahap awal oleh tim peneliti mendapatkan skor rata-rata 3,93. Hal ini berarti produk dapat dikategorikan layak dan dapat diujicobakan.

2) Hasil Uji Kelayakan Ahli Media

Materi modul dalam penelitian ini diuji dengan menggunakan format penilaian berbentuk angket dengan skala 5. Angket berisi 36 butir pernyataan yang dikelompokkan dalam 6 aspek yaitu konsistensi, bentuk dan ukuran huruf, format, pengorganisasian, daya tarik, ruang (spasi kosong). Hasil rekapitulasi dapat dilihat selengkapnya dalam lampiran. Hasil rata-rata penilain disajikan dalam tabel berikut: 
Tabel 2. Uji Kelayakan Ahli Media

\begin{tabular}{llll} 
No & \multicolumn{1}{c}{ Aspek Penilaian } & Rata-Rata Skor & $\begin{array}{r}\text { Katego } \\
1\end{array}$ \\
2 & Konsistensi & 4,40 & Layak \\
3 & Fontuk dan Ukuran Huruf & 3,86 & Layak \\
4 & Pengorganisasian & 4,00 & Layak \\
5 & Daya Tarik & 3,88 & Layak \\
6 & Spasi Kosong & 4,00 & Layak \\
Rata-Rata Skor Ahli Media & 4,00 & Layak \\
\end{tabular}

Dari hasil validasi oleh ahli media di atas dapat disimpulkan bahwa pengembangan produk tahap awal oleh tim peneliti mendapatkan skor rata-rata 4,02. Hal ini berarti produk dapat dikategorikan layak dan dapat diujicobakan.

3) Hasil Uji Kelayakan oleh Praktisi Pengajaran

Materi modul dalam penelitian ini diuji dengan menggunakan format penilaian berbentuk angket dengan skala 5. Angket berisi 36 butir pernyataan yang dikelompokkan dalam 4 aspek yaitu kelayakan isi, penggunaan bahasa, penyajian dan kegrafikan. Hasil rekapitulasi dapat dilihat selengkapnya dalam lampiran. Hasil rata-rata penilaian disajikan dalam tabel berikut:

Tabel 3. Uji Kelayakan oleh Praktisi Pengajaran

\begin{tabular}{llll} 
No & Aspek Penilaian & Rata-Rata Skor & \multicolumn{1}{c}{ Kategori } \\
1 & Isi & 3,91 & Layak \\
2 & Penggunaan Bahasa & 4,00 & Layak \\
3 & Penyajian & 3,89 & Layak \\
4 & Kegrafikan & 4,33 & Sangat Layak \\
Rata-Rata Skor Praktisi & $\mathbf{4 , 0 3}$ & Layak \\
Pengajaran & &
\end{tabular}

Dari hasil validasi oleh Praktisi pengajaran di atas dapat disimpulkan bahwa pengembangan produk tahap awal oleh tim peneliti mendapatkan skor rata-rata 4,03. Hal ini berarti produk dapat dikategorikan layak dan dapat diujicobakan.

b. Revisi Produk

Setelah mendapatkan penilaian dan masukan dari ahli materi, ahli media dan praktisi pembelajaran di atas, tim peneliti kemudian merevisi produk awal dengan memperhatikan beberapa masukan dan koreksi dari tim ahli di atas. 
Al-Lisan. Journal Bahasa \& Pengajarannya

ISSN 2442-8965 \& E ISSN 2442-8973

Volume 4 Nomor 1- Februari 2019

http://journal.iaingorontalo.ac.id/index.php/al

c. Uji Coba Pengembangan

Uji coba pengembangan dilakukan pada kelompok kecil dan kelompok besar. Pada tahap ini peserta dimintai responnya terhadap produk yang dikembangkan. Respon mahasiswa terhadap penggunaan modul Basic English Grammar bertujuan untuk memperoleh informasi dan masukan pada rancangan akhir produk berupa modul pembelajaran.

1) Data Uji Coba Kelompok Kecil

Uji coba kelopok kecil dilakukan terhadap 10 orang mahasiswa. Uji coba diawali dengan pembagian draft modul yang sudah direvisi dan dinyatakan layak oleh ahli. Setelah itu dilanjutkan dengan penjelasan singkat mengenai isi modul. Selanjutnya mahasiswa diberikan waktu untuk melihat dan membaca draft modul dan pada saat yang bersamaan mahasiswa diberikan format penilaian berupa angket dengan skala 5. Angket berisi 25 butir pernyataan yang dikelompokkan dalam 4 aspek yaitu kelayakan isi, penggunaan bahasa, penyajian dan kegrafikan. Hasil rekapitulasi dapat dilihat selengkapnya dalam lampiran. Hasil rata-rata penilain disajikan dalam tabel berikut:

Tabel 4. Uji Coba Kelompok Kecil

\begin{tabular}{|c|c|c|c|c|}
\hline No & \multicolumn{2}{|c|}{ Aspek Penilaian } & Rata-Rata Skor & Kategori \\
\hline 1 & \multicolumn{2}{|l|}{ Isi } & 4,33 & Sangat Layak \\
\hline 2 & \multicolumn{2}{|c|}{ Penggunaan Bahasa } & 4,45 & Sangat Layak \\
\hline 3 & \multicolumn{2}{|c|}{ Penyajian } & 4,40 & Sangat Layak \\
\hline 4 & \multicolumn{2}{|c|}{ Kegrafikan } & 4,60 & Sangat Layak \\
\hline $\begin{array}{l}\text { Rata } \\
\text { Mah: }\end{array}$ & & Respon & 4,45 & Sangat Layak \\
\hline
\end{tabular}

Dari hasil di atas, respon mahasiswa terhadap draft modul pada kelompok kecil menunjukkan bahwa modul berada pada kategori sangat layak dengan rata-rata skor 4,45. Dari hasil ini tim peneliti melakukan revisi pada beberapa bagian modul untuk kemudian dapat diujicobakan pada taha selanjutnya.

2) Data Uji Coba Kelompok Besar

Uji coba kelompok besar ini dilakukan terhadap 21 orang mahasiswa. Uji coba diawali dengan pembagian draft modul yang sudah direvisi dan dinyatakan layak oleh ahli. Setelah itu dilanjutkan dengan penjelasan singkat mengenai isi modul. Selanjutnya mahasiswa diberikan waktu untuk melihat dan membaca draft modul dan pada saat yang bersamaan mahasiswa diberikan format penilaian berupa angket dengan skala 5. Angket berisi 25 butir pernyataan yang dikelompokkan dalam 4 aspek yaitu kelayakan isi, 
Al-Lisan. Journal Bahasa \& Pengajarannya

ISSN 2442-8965 \& E ISSN 2442-8973

Volume 4 Nomor 1- Februari 2019

http://journal.iaingorontalo.ac.id/index.php/al

penggunaan bahasa, penyajian dan kegrafikan. Hasil rekapitulasi dapat dilihat selengkapnya dalam lampiran. Hasil rata-rata penilain disajikan dalam tabel berikut:

Tabel 5. Uji Coba Kelompok Besar

\begin{tabular}{|c|c|c|c|c|}
\hline No & \multicolumn{2}{|c|}{ Aspek Penilaian } & Rata-Rata Skor & Kategori \\
\hline 1 & \multicolumn{2}{|l|}{ Isi } & 4,80 & Sangat Layak \\
\hline 2 & \multicolumn{2}{|l|}{ Penggunaan Bahasa } & 4,75 & Sangat Layak \\
\hline 3 & \multicolumn{2}{|l|}{ Penyajian } & 4,90 & Sangat Layak \\
\hline 4 & \multicolumn{2}{|l|}{ Kegrafikan } & 4,75 & Sangat Layak \\
\hline Rat & Skor & Respon & 4,80 & Sangat Layak \\
\hline
\end{tabular}

Dari hasil di atas, respon mahasiswa terhadap draft modul pada kelompok besar menunjukkan bahwa modul berada pada kategori sangat layak dengan rata-rata skor 4,80. Dari hasil ini tim peneliti melakukan revisi dan kemundian menghasilkan produk akhir dari pengembangan modul pembelajaran Basic English Grammar yang diperuntukan bagi mahasiswa Semester Tiga Tadris Bahasa Inggris.

\section{B. Pembahasan}

Pengembangan Bahan Ajar English Grammar berbentuk Modul menggunakan model pengembangan Four-D yang dikembangkan oleh Thiagarajan dan Semmel. Penelitian pengembangan ini dilakukan melalui empat tahap yaitu pendefinisian (define), perancangan (design), pengembangan (develop), dan penyebaran (disseminate).

1. Define (Pendefinisian)

Langkah awal pada tahap ini adalah mengumpulkan informasi dan menganalisis kebutuhan mahasiswa dan dosen bahasa Inggris di lingkungan Fakultas Ilmu Tarbiyah dan Keguruan IAIN Sultan Amai Gorontalo. Pengumpulan informasi kebutuhan terhadap pengembangan produk berupa modul atau bahan ajar pada mata kuliah Basic English Grammar ini dilakukan dengan menyebarkan angket kebutuhan dan melalui Focus Group Discussion (FGD). Dari hasil angket dan kegiatan focus group discussion ini kemudian diuraikan dan dianalisis segala bentuk kebutuhan dosen dan mahasiswa sebagai langkah awal dalam mengembangkan produk berupa modul atau bahan ajar pada mata kuliah Basic English Grammar di Jurusan Tadris Bahasa Inggris FITK IAIN Sultan Amai Gorontalo. Hasil analisis pada tahap ini dapat digambarkan bahwa mahasiswa memerlukan modul atau buku pegangan selama proses pembelajaran. Modul 
Al-Lisan. Journal Bahasa \& Pengajarannya

ISSN 2442-8965 \& E ISSN 2442-8973

Volume 4 Nomor 1- Februari 2019

http://journal.iaingorontalo.ac.id/index.php/al

yang baku dan sesuai dengan standar kompetensi juga menyesuaikan dengan karakteristik mahasiswa itu sendiri.

\section{Design (Perancangan)}

Pada tahap design, tim peneliti menyusun tes, memilih media yang tepat, dan memilih format yang akan digunakan dalam pengembangan media, serta menulis naskah modul. Penyusunan tes merupakan langkah awal yang memhubungkan antara tahap define dan tahap design. Penyusunan tes digunakan untuk mengukur pencapaian kompetensi mahasiswa Mata Kuliah English Grammar pada level basic. Bentuk tes yang digunakan adalah option test. Pemilihan bentuk tes ini didasarkan pada tujuan akhir yang ingin dicapai bahwa mahasiswa mampu menguasai dan memahami tata bahasa inggris sederhana khsusunya pada materi parts of speech dan determiner.

Tahap selanjutnya adalah pemilihan media, Pemilihan media didasarkan pada analisis yang dilakukan pada tahap define. Berdasarkan analisis yang dilakukan pada tahap define, mahasiswa membutuhkan bahan ajar yang dapat membantu mahasiswa untuk belajar mandiri, serta dapat meningkatkan pencapaian kompetensi mahasiswa pada MK English grammar. Sehingga, media yang dipilih berupa Bahan Ajar English Grammar Berbentuk Modul.

Format modul terdiri dari komponen-komponen yang harus ada dalam modul. Format modul disusun dengan memperhatikan komponen-komponen modul yang dikemukakan oleh Depdiknas (2008). Komponen utama dalam modul merupakan kegiatan belajar. Kegiatan belajar merupakan kunci utama tercapainya tujuan pembelajaran pada setiap kompetensi dasar yang mana kegiatan belajar tersebut berisi uraian materi beserta contoh dan penyelesaian, rangkuman, tes formatif, dan tugas.

Selanjutnya penulisan modul. Modul yang ditulis berjudul Basic English Grammar; Mudah \& Praktis. Penulisan modul didasarkan pada Garis Besar Konten Modul dengan memperhatikan elemen mutu modul yang dikemukakan Depdiknas (2008) dan Azhar Arsyad (2014). Modul ditulis secara runtut sesuai dengan kompetensi dasar, dengan desain menarik dan berwarna. Modul yang disusun merupakan satu kesatuan bahan ajar yang didesain untuk dapat digunakan belajar mandiri mahasiswa serta meningkatkan kompetensi mahasiswa pada Mata Kuliah English Grammar. 
Al-Lisan. Journal Bahasa \& Pengajarannya

ISSN 2442-8965 \& E ISSN 2442-8973

Volume 4 Nomor 1- Februari 2019

http://journal.iaingorontalo.ac.id/index.php/al

3. Develop (Pengembangan)

Pada tahap develop, tim peneliti melakukan validasi dan uji coba pengembangan. Bahan Ajar English Grammar Berbentuk Modul yang telah dicetak kemudian diuji kelayakannya oleh ahli materi, ahli media, dan praktisi pengajaran. Hasil validasi menunjukkan bahwa Bahan Ajar English Grammar berbentuk Modul layak diujicobakan. Kategori layak diartikan bahwa Bahan Ajar English Grammar berbentuk Modul dari segi materi memiliki kualitas isi, kebahasaan, dan penyajian yang baik untuk menunjang proses pembelajaran. Dari segi media memiliki daya tarik, format serta konsistensi dalam layout modul yang baik dengan pemilihan bentuk dan ukuran huruf yang tepat, serta pengorganisasian yang memudahkan mahasiswa yang dilengkapi dengan ruang (spasi kosong) untuk menjawab soal dan pemisah antar unit.

4. Disseminate (Penyebarluasan)

Pada tahap ini, tim peneliti membagikan produk kepada mahasiswa yang berbentuk cetak. Tim peneliti juga akan memberikan produk ini untuk dijadikan salah satu arsip pada persputakaan kampus atau prodi. Pada tahap ini pula tim peneliti akan menyebarluaskan hasil penelitian ini melalui jurnal nasional.

\section{KESIMPULAN}

Berdasarkan hasil penelitian dan pembahasan, dapat disimpulkan beberapa hal sebagai berikut: Pengembangan Bahan Ajar Basic English Grammar pada dikembangkan menggunakan model Four-D yang dilakukan melalui 4 tahapan pokok yaitu pendefinisian (define), perancangan (design), pengembangan (develop), dan penyebaran (diseseminate).

1. Define, pada tahap ini, diperoleh hasil bahwa mahasiswa membutuhkan bahan ajar yang dapat meningkatkan kompetensi mahasiswa pada mata kuliah English Grammar, serta dapat membantu mahasiswa untuk belajar mandiri.

2. Design, pada tahap ini, diperoleh hasil bahwa bahan ajar yang sesuai dengan kebutuhan mahasiswa yakni, Modul Basic English Grammar.

3. Develop, pada tahap ini Modul disusun berdasarkan kedua tahap di atas dan divalidasi oleh ahli materi, media dan praktisi pembelajaran.

4. Disseminate, pada tahap ini modul dibagikan kepada mahasiswa dan hasil penelitian akan disebarkan melalui jurnal nasional. 


\section{DAFTAR PUSTAKA}

Atwi-Suparman, M..(2012). Desain Intruksional Modern. Jakarta : Erlangga

Depdiknas 2003. Pedoman Penulisan Modul. Jakarta: Direktorat PLP, Ditjen Dikdasmen. Depdiknas.

Depdiknas. 2008. Panduan Pengembangan Bahan Ajar. Departemen Pendidikan Nasional.

Dick, W., Carey, L.,dan Carey, J.O. 2009. The Systematic Design of Instruction. New Jersey: Pearson.

Direktorat Jenderal Manajemen Pendidikan Dasar Dan Menengah Direktorat Pembinaan Sekolah menengah Atas. (2008). Panduan Penulisan Butir Soal. Departemen Pendidikan Nasional.

Gerot, Linda and Wignell, Peter. 1995. Making Sense of Functional Grammar. NSW : Antipodean educational Enterprises.

Harmer, Jeremy. 2001. The Practice of English Language Teaching, $3^{\text {rd }}$ Ed, New York: Pearson Education Limited.

Hutchinson, Tom \& Eunice Torres. 1994. The textbook as agent of change. English Language Teaching Journal, 48,pp. 315-328.

Ika Lestari. 2013. Pengembangan Bahan Ajar Berbasis Kompetensi. Padang:Akademia Permata.

Iskandarwassid, dan H. Dadang Sunendar. 2011. Strategi Pembelajaran Bahasa. Bandung: PT Remaja Rosdakarya.

Leech, Geofrey. 1982. Priciples of Pragmatics. London dan New York: Longman. Mulyasa. (2006). Kurikulum Berbasis Kompetensi. Bandung: PT Remaja Rosdakarya. Opara, Jacinta A dan Oguzor, N Silas. (2011). Inquiry Instructional Method and the School Science Currículum. [Online]. Tersedia: http://maxwellsci.com/print/crjss/v3-188-198.pdf (November 2017)

Pingel F. 2009. A guide Book on the textbook research and textbook revision. _: United Nations Educational, Scientific and Cultural Organization.

Rudi Susilana.Cepi Riyana,.2008. Media Pembelajaran. Bandung :CV WacanaPrima Sahertian W Demaja Christiana, 2004. Pengaruh Penggunaan Bahan Ajar Dan Gaya Belajar Terhadap Hasil Belajar, Artikel

Swan, Michael. 2005.Practical English Usage. Third edition. New York: Oxford University Press 
Al-Lisan. Journal Bahasa \& Pengajarannya

ISSN 2442-8965 \& E ISSN 2442-8973

Volume 4 Nomor 1- Februari 2019

http://journal.iaingorontalo.ac.id/index.php/al

Hendra Eka Putra \& Ridianto. 2016. Pengembangan Model Materi Ajar Mata Kuliah Bahasa Inggris II Berbasis Kebutuhan Mahasiswa Program Studi Akuntansi Syariah STAIN Batusangkar. Ta'dib, Volume 19, No. 2 (Desember 2016)

Syahrul Mubaroq. 2015. "Pengembangan bahan ajar grammar one berbasis mobile learning di lembaga kursus Global English Pare - Kediri”. Skripsi. Program Studi Teknologi Pembelajaran, Universitas Negeri Malang.

Thiagarajan, S., Semmel, D. S \& Semmel, M. I. 1974. Instructional Development for Training Teachers of Expectional Children. Minneapolis,Minnesota: Leadership Training Institute/Special Education, University of Minnesota

Tomlinson, Brian. 1998. Materials Development in Language Teaching. Cambridge: Cambridge University Press.

Wardhana, Yana. 2010. Teori belajar dan mengajar. Bandung: Pribumi Mekar 